\title{
Performance of skin biopsies by general practitioners
}

\author{
Lorna J McWilliam, Fiona Knox, Nafisa Wilkinson, Pravin Oogarah
}

Abstract

Objective - To evaluate and appraise skin biopsies performed by general practitioners and compare their performance with that of hospital doctors.

Design-Retrospective analysis of histology records.

Setting-University hospital.

Subjects-Records of 292 skin biopsy specimens obtained by general practitioners and 324 specimens obtained by general and plastic surgeons.

Main outcome measures-Clinical and pathological diagnoses and completeness of excision.

Results - The number of specimens received from hospital surgeons and general practitioners increased over the study period; the proportion of specimens from general practitioners rose from $17 / 1268(1.3 \%)$ in 1984 to $201 / 2387(8.7 \%)$ in 1990 . The range of diagnoses was similar among hospital and general practitioner cases, although malignancy was commoner in hospital cases $(63 / 324(19 \%) v 14 / 292(5 \%)$ in general practitioner cases; $\left.\chi^{2}=28, p<0.00001\right)$. Completeness of excision was less common among general practitioners than hospital surgeons $(150 / 233$ (3/15 malignant) $\left.v 195 / 232(57 / 63) ; \chi^{2}=22, \mathrm{p}<0.00001\right)$.

Conclusions - The increase in minor surgery has implications for the staffing and finance of histopathology departments. General practitioners must be given proper training in performing skin biopsies, and all specimens should be sent for examination.

\section{Introduction}

The number of skin biopsy specimens received in our department has increased since the introduction of the new general practitioner contract in April 1990. Our initial impression was that biopsy specimens received from general practitioners were generally less adequately excised and of poorer quality than those received from plastic and general surgeons. We designed a study to appraise the biopsy specimens received from general practitioners and to compare them with similarly sized specimens received from plastic and general surgeons in our hospital.

\section{Methods}

We examined the records of all skin biopsy specimens

Department of

Pathological Sciences, Division of Histopathology, University Hospital of South Manchester, Manchester M20 8LR Lorna J McWilliam MRCPATH, consultant histopathologist

Fiona Knox, MRCPATH, consultant histopathologist Nafisa Wilkinson, MB, senior registrar

Pravin Oogarah, MB, registrar

Correspondence to:

Dr McWilliam.

BMF 1991;303:1177-9 years. Now increasing in size and itchy, possible malignant change."

For comparison we used random number tables to select a similar number of records of skin biopsy specimens from hospital cases during the same period. Cases in which the specimens were more than $3.0 \mathrm{~cm}$ in diameter were excluded so that the specimens were similar to those taken in general practice. The same data were recorded for hospital specimens as for the general practitioner specimens, and the data were compared by the $\chi^{2}$ test.

\section{Results}

We found a steady rise in the number of skin biopsy specimens received from both hospital surgeons and general practitioners over the past seven years, with a notable increase in specimens from general practitioners mainly since 1988 (table I). General practitioners had excised significantly more specimens from men than had hospital surgeons $\left(\chi^{2}=5 \cdot 7, \mathrm{df}=1\right.$; $\mathrm{p}=0.017)$ and there were significantly more specimens from the head and neck region taken by surgeons than by general practitioners $\left(\chi^{2}=37, \mathrm{df}=2 ; \mathrm{p}<0.00001\right.$; table II).

Similar numbers of benign naevi and basal cell papillomas were found in both groups, but there was a much higher proportion of basal cell carcinomas in hospital cases and of warts and fibroepithelial polyps in general practitioner cases (table III). The ratio of al

TABLE I - Numbers of skin biopsy specimens sent for histopathological examination by surgeons and general practitioners, Withington Hospital, 1984-91

\begin{tabular}{|c|c|c|c|c|}
\hline Year & $\begin{array}{l}\text { No } \\
\text { taken at } \\
\text { hospital }\end{array}$ & $\begin{array}{l}\text { No taken by } \\
\text { general practitioner }\end{array}$ & Total & $\begin{array}{c}\% \text { Of total } \\
\text { taken by } \\
\text { general practitioner }\end{array}$ \\
\hline \multicolumn{5}{|l|}{ 1984: } \\
\hline Jan-Mar & 267 & 4 & 271 & 1.5 \\
\hline Apr-Jun & 315 & 3 & 318 & 0.9 \\
\hline Jul-Sep & 326 & 5 & 331 & 1.5 \\
\hline Oct-Dec & 345 & 5 & 348 & 1.4 \\
\hline \multicolumn{5}{|l|}{ 1985: } \\
\hline Jan-Mar & 287 & 1 & 288 & $0 \cdot 3$ \\
\hline Apr-Jun & 329 & 3 & 331 & 0.9 \\
\hline Jul-Sep & 332 & 7 & 339 & $2 \cdot 1$ \\
\hline Oct-Dec & 334 & 5 & 337 & 1.5 \\
\hline \multicolumn{5}{|l|}{ 1986: } \\
\hline Jan-Mar & 319 & 6 & 325 & 1.8 \\
\hline Apr-Jun & 297 & 4 & 301 & $1 \cdot 3$ \\
\hline Jul-Sep & 464 & 12 & 476 & 2.5 \\
\hline Oct-Dec & 422 & 6 & 428 & 1.4 \\
\hline \multicolumn{5}{|l|}{ 1987: } \\
\hline Jan-Mar & 438 & 5 & 443 & $1 \cdot 1$ \\
\hline Apr-Jun & 418 & 5 & 423 & 1.2 \\
\hline Jul-Sep & 473 & 6 & 483 & 1.2 \\
\hline Oct-Dec & 495 & 8 & 503 & 1.6 \\
\hline \multicolumn{5}{|l|}{ 1988: } \\
\hline Jan-Mar & 407 & 11 & 418 & $2 \cdot 6$ \\
\hline Apr-Jun & 419 & 7 & 426 & 1.6 \\
\hline Jul-Sep & 511 & 14 & 525 & $2 \cdot 7$ \\
\hline Oct-Dec & 516 & 20 & 536 & 3.7 \\
\hline \multicolumn{5}{|l|}{ 1989: } \\
\hline Jan-Mar & 452 & 31 & 483 & $6 \cdot 4$ \\
\hline Apr-Jun & 459 & 30 & 489 & $6 \cdot 1$ \\
\hline Jul-Sep & 550 & 34 & 584 & $5 \cdot 8$ \\
\hline Oct-Dec & 488 & 19 & 507 & $3 \cdot 7$ \\
\hline \multicolumn{5}{|l|}{ 1990: } \\
\hline $\mathrm{Jan}-\mathrm{Mar}$ & 430 & 20 & 450 & $4 \cdot 4$ \\
\hline Apr-Jun & 502 & 58 & 560 & $10 \cdot 4$ \\
\hline Jul-Sep & 608 & 70 & 678 & $10 \cdot 3$ \\
\hline Oct-Dec & 632 & 61 & 693 & 8.8 \\
\hline \multirow{2}{*}{$\begin{array}{l}\text { 1991: } \\
\text { Jan-Mar }\end{array}$} & & & & \\
\hline & 502 & 58 & 560 & $10 \cdot 4$ \\
\hline
\end{tabular}


malignant to all non-malignant lesions was higher in the hospital cases than the general practitioner cases $\left(\chi^{2}=28, \mathrm{df}=1 ; \mathrm{p}<0.0001\right)$.

The quality of clinical information given on request cards was similar for both groups. Accuracy of clinical recognition of all lesions was significantly less among general practitioners than among hospital surgeons $\left(\chi^{2}=27, \mathrm{df}=1 ; \mathrm{p}<0.00001\right)$ and incomplete excisions were significantly more common in general practitioner specimens $\left(\chi^{2}=22, \mathrm{df}=1 ; \mathrm{p}<0.00001\right)($ table IV).

\section{Discussion}

Minor surgery in general practice is not new and indeed is successful and cost effective ${ }^{12}$ with benefits for both patients and doctors. It provides patients with a swift service in a user friendly environment and has minimal complications. ${ }^{14}$ Skin biopsy in primary care was discussed in detail ${ }^{3-5}$ before the publication of the white paper Promoting Better Health. ${ }^{6}$ Growing interest in minor surgery among general practitioners has been accelerated by the new general practitioner contract,? which encourages minor surgery by financial remuneration. ${ }^{8}$ There are now courses for accreditation and atlases of minor surgical practice for general practitioners. ${ }^{910}$

The effect of the increase in minor surgery has been examined, ${ }^{11-14}$ and with regard to histopathology services, implications have been suggested for workload and staffing. Expansion of a recent pilot scheme for minor surgery in general practice ${ }^{14}$ proved difficult because of the increased workload generated for the local pathology department, and the study's authors emphasise that the effect on histopathology services must be considered when planning services.. So far any "knock on" effect in laboratories has been disregarded. The trend in minor surgery is still increasing. In the four months after the end of the study period we received a further 225 skin specimens from general practitioners. If the workload continues to rise at this

TABLE II-Details of patients who had skin biopsies by general practitioners and hospital surgeons

\begin{tabular}{lcc}
\hline & $\begin{array}{c}\text { General practitioner } \\
(\mathrm{n}=292)\end{array}$ & $\begin{array}{c}\text { Hospital } \\
(\mathrm{n}=324)\end{array}$ \\
\hline Sex of patient: & 160 & \\
$\quad$ Female & $128^{\star}$ & 111 \\
$\quad$ Male & 4 & 1 \\
$\quad$ Unknown & $45 \cdot 9(9-93)$ & $44 \cdot 8(1-94)$ \\
Mean (range) age of patients (years) & 99 & $190 \dagger$ \\
Site of lesions: & 117 & 75 \\
$\quad$ Head and neck & 62 & 50 \\
$\quad$ Trunk & 14 & 9 \\
$\quad$ Limbs & & \\
$\quad$ Not stated & & \\
\hline$\chi^{2}=5 \cdot 7, \mathrm{df}=1 ; \mathrm{p}=0 \cdot 017$ compared with hospital group. \\
$t \chi^{2}=37, \mathrm{df}=2 ; \mathrm{p}<0 \cdot 00001$ compared with general practitioners.
\end{tabular}

TABLE III - Pathological diagnosis in skin biopsy specimens taken by general practitioners and hospital surgeons. Figures are numbers (percentages)

\begin{tabular}{lcr}
\hline & $\begin{array}{c}\text { General practitioner } \\
(\mathbf{n}=292)\end{array}$ & $\begin{array}{c}\text { Hospital } \\
(\mathbf{n}=324)\end{array}$ \\
\hline Benign naevus & $86(30)$ & $96(30)$ \\
Basal cell papilloma & $47(16)$ & $36(11)$ \\
Fibroepithelial polyp or squamous & $33(11)$ & $11(3)$ \\
$\quad$ papilloma & $25(9)$ & $5(2)$ \\
Verrucca vulgaris (wart) & $21(7)$ & $27(8)$ \\
Epidermoid or pilar cyst & $22(8)$ & $31(10)$ \\
Benign connective tissue tumour & $3(1)$ & $6(2)$ \\
Benign adnexal tumour. & $6(2)$ & $55(17)$ \\
Basal cell carcinoma & $5^{\star}(1)$ & $3(1)$ \\
Squamous cell carcinoma & $3(1)$ & $5(2)$ \\
Squamous cell carcinoma in situ & $1(0 \cdot 3)$ & $47(15)$ \\
Malignant melanoma & $30(10)$ & $2(1)$ \\
Miscellaneous & $10(3)$ & \\
Inadequate biopsy specimen &
\end{tabular}

$\chi^{2}=28, \mathrm{df}=1 ; \mathrm{p}<0.0001$ (all malignant $v$ all non-malignant lesions). ${ }^{\star}$ Includes one re-excision.
TABLE IV - Details of biopsy specimens excised by general practitioners and hospital surgeons. Figures are numbers (percentages) unless stated otherwise

\begin{tabular}{|c|c|c|}
\hline & $\begin{array}{c}\text { General } \\
\text { practitioner } \\
(\mathrm{n}=292)\end{array}$ & $\begin{array}{l}\text { Hospital } \\
(n=324)\end{array}$ \\
\hline Mean (range) size of biopsy specimen $(\mathrm{cm})$ & $1 \cdot 3(0 \cdot 3-3 \cdot 0)$ & $1 \cdot 5(0 \cdot 3-3 \cdot 0)$ \\
\hline Mean (range) size of lesion $(\mathrm{cm})$ & $0 \cdot 8(0 \cdot 3-2 \cdot 5)$ & $0 \cdot 8(0 \cdot 3-2 \cdot 0)$ \\
\hline \multicolumn{3}{|l|}{ Quality of clinical information ${ }^{\star}$ : } \\
\hline Good or average & $169(58)$ & $191(59)$ \\
\hline Poor & $123(42)$ & $133(41)$ \\
\hline \multicolumn{3}{|l|}{$\begin{array}{l}\text { Agreement between clinical and } \\
\text { pathological diagnosist: }\end{array}$} \\
\hline All cases & $120 / 292(41)$ & $202 / 324(62)$ \\
\hline Malignant cases & $4 / 14(29)$ & $57 / 63(90)$ \\
\hline \multicolumn{3}{|l|}{ Completeness of excision $\ddagger$ : } \\
\hline Complete & $150(64)$ & $195(84)$ \\
\hline Incomplete & $83(36)$ & $37(16)$ \\
\hline \multicolumn{3}{|l|}{$\begin{array}{l}\text { Completeness of excision of } \\
\text { premalignant and malignant lesions: }\end{array}$} \\
\hline Complete & $3(20) \Omega$ & $57(90)$ \\
\hline Incomplete & $12(80) \|$ & $6(10)$ \\
\hline Inadequate biopsy specimen & $10(3 \cdot 4)$ & $2(0 \cdot 6)$ \\
\hline
\end{tabular}

$\star \chi^{2}=0.35, \mathrm{df}=1 ; \mathrm{p}=0.55$

$+x^{2}=27, \mathrm{df}=1 ; \mathrm{p}<0.00001$.

$\ddagger$ Excluding fibroepithelial polyps, cysts, and non applicable cases $\left(\chi^{2}=22\right.$, $\mathrm{df}=1 ; \mathrm{p}<0.00001$ ).

Includes one re-excision.

|Including one incisional biopsy specimen.

rate both finance and staffing will have to be reexamined.

Although the number of skin biopsies performed by general practitioners is increasing, we found no compensatory decrease in skin biopsies performed in the hospital; indeed these examinations are also increasing. This is due to increased referral rates and possibly reflects increased awareness among the public and the medical profession of skin cancer and melanoma.

The higher percentage of malignant lesions in hospital cases than general practitioner cases $(19 \% v$ $5 \%$ ) presumably means that most malignant lesions are correctly identified by general practitioners and the patients referred to hospital. Most of these cancers were basal cell carcinomas, lesions which are usually fairly easy to identify clinically. However, a small number of premalignant and malignant lesions were not recognised by general practitioners, and, more importantly $80 \%$ of such lesions were incompletely excised. Follow up specimens after further excision were received in only one of these malignant cases during the study period. Clinical recognition of malignant lesions in hospital patients was correct in $90 \%$ of cases and $90 \%$ of malignant lesions were completely excised. If benign tumours are included then $84 \%$ of lesions were completely excised in hospital compared with $64 \%$ in general practice.

The finding that skin lesions were generally less adequately excised by general practitioners highlights the need for proper training in minor surgery. Anxieties have been expressed about the provision of training for minor surgery in the career structure of general practitioner trainees. ${ }^{1516}$ Though incomplete excision probably has no clinical consequences in most cases, initial complete excision of a lesion may obviate the need for further treatment and is good surgical practice.

All lesions should be sent for histological examination. ${ }^{410} \mathrm{As}$ far as we are aware virtually all skin specimens removed in the hospital by plastic and general surgeons are referred for histological examination, but not all specimens removed by general practitioners are referred $(M$ Whitaker, unpublished observations). A recent study found that of 183 skin biopsy specimens taken by general practitioners (excluding cysts), only 116 were sent for histological examination. ${ }^{14}$ Three of these specimens were found to be malignant. Some of the factors taken into account by general practitioners when deciding whether to refer are innocuous appearance, size, pigmentation, 
and length of history ( $M$ Whitaker, personal communication). Some, albeit few, malignant lesions were not clinically recognised in this study and doctors should be wary of discarding skin specimens as malignant and incompletely excised lesions may recur. Referral for histological examination avoids delayed diagnosis and should effect prompt and adequate further treatment if required.

In conclusion, the performance of skin biopsies by general practitioners could be improved. All skin specimens should be sent for histological examination for feedback of both diagnostic skill and quality of excision.

We thank Dr Mark Whitaker and Dr Emyr Benbow for their advice and Miss Deborah Buckley for typing the manuscript.

1 Coopers and Lybrand Associates. The cost effectiveness of general practice. London: British Medical Association, 1983. (General Medical Services Committee discussion document.)
2 Brown JS. Minor operations in general practice. BMF 1979;i:1609-10.

Wall DW. Minor surgery in general practice. In: Gray DJP, ed. The medical annual 1985. Bristol: Wright, 1985:74-84.

4 Wall DW. A review of minor surgery in general practice in the United Kingdom. Fam Pract 1987:4:322-9.

5 Sharman J. Patients response to a general practitioner minor surgery service. Practitioner 1986;230:27-9.

6 Department of Health and Social Security. Promoting better health: the government's programme for improving primary health care. London: $\mathrm{HMSO}$ 1987. (Cm 249.)

7 Department of Health and Welsh Office. General practice in the National Health Service: a new contract. London: $\mathrm{DoH}$ and Welsh Office, 1989.

8 Department of Health. Statement of fees and allowances. London: DoH, 1990.

9 Fry J, Higton I, Stephenson J. Colour atlas of minor surgery in general practice. London: Kluwer, 1990.

10 Brown JS. Minor surgery. A text and atlas. London: Chapman and Hall, 1986.

11 Galloway M Senadhira A Labs take the strain. Health Service foumal $1990 ; 100: 1037$

12 Slater D. Screening and the 1990 contract. BMF 1990;300:1074.

13 J Jenk. Scring and the 1990 contract. BMY 1990:300:1074.

13 Jenkins. Sc Wanis $M$, Schieden H. In BMf 1990;300:825-6. scheme for minor surgery in general practice. Health Trends 1990;2:57-9. scheme for minor surgery in general practice. Health Trends 1990;2:57-9.
Pringle M, Hasler J, De Marco P. Training for minor surgery in general Pringle M, Hasler J, De Marco P. Training for minor surgery in
practice during preregistration surgical posts. BMf 1991;302:830-2. practice during preregistration surgical posts. $B M \mathcal{F} 1991 ; 302: 830-2$.
Chew C. Training for minor surgery in general practice during preregistration Chew C. Training for minor surgery in ge
surgical posts. BMf 1991;302:1211-2.

(Accepted 28 August 1991)

\section{Skin biopsy in general practice}

\section{R B Williams, A H Burdge, S Lewis Jones}

Maelor General Hospital, Wrexham, Clwyd LL137TD

R B Williams, MRCPATH, consultant histopathologist A H Burdge, MRCPATH, consultant histopathologist S Lewis Jones, MRCP, consultant dermatologis

Correspondence to: Dr Williams.

BMF 1991;303:1179-80 practitioner contract was introduced.

\section{Methods and results}

Removal of minor skin lesions by general practitioners has several advantages for patients. It reduces waiting times and travelling distances, the familiar environment lessens anxiety, and appointments may be less inconvenient. It is important, however, that general practitioners are adequately trained. We studied the referral of skin specimens to our histology department during 1989-90, around the time when the new general

We searched the histopathology database for statistics on the work referred to the department during 1989 and 1990. The department, which serves 60 general practices with 100 general practitioners, received 243 biopsy specimens from general practitioners during 1989, 233 of which were skin specimens. In 1990 general practitioners sent 357 specimens, 338 from skin lesions. Specimens from general practitioners comprised $2 \cdot 8 \%$ of the department's work in 1989 and $4 \cdot 1 \%$ in 1990 . All referral letters included a clinical diagnosis.

Six $(2.6 \%)$ of the skin specimens were from histologically malignant lesions in 1989 compared with 20 $(5.9 \%)$ in $1990(p=0.024$; Fisher's exact test). Malignancy was clinically diagnosed in two of the six cases in 1989.

Three types of malignancy were found (table): basal cell carcinoma ( 14 specimens), squamous cell carcinoma (eight), and malignant melanoma (four). The four malignant melanomas were excised in 1990 and represented $14 \cdot 2 \%$ of all melanomas received by the laboratory in that year.

\section{Comment}

Paver suggested that suitable techniques for family practitioners include cryosurgery, electrocautery, shave biopsy, and simple excision. ${ }^{1}$ Brundel uses punch and excision biopsy. ${ }^{2}$ All the skin specimens that we received were from excision biopsies.

From 1989 to 1990 there was a $45 \%$ increase in skin biopsy by general practitioners with a threefold increase in the number of malignant lesions removed.
The reasons for this increase are not clear; there was no corresponding decrease in the department's work load over the same period. Either general practitioners removed more lesions or they submitted more for histological examination.

Elderly patients, in particular, benefit from general practitioner surgery, and $15 \%$ of our biopsy specimens were from patients aged over 70 . It is important, however, for surgeries to have adequate equipment and sterilisation procedures and that resuscitation equipment is available. In addition, lack of training and expertise among general practitioners may result in unnecessary biopsies, such as excision of keloid scars, or an inappropriate technique being used.

Failure to give adequate preoperative information is too common in the NHS generally, and patients must be informed about complications, such as wound infection and keloid formation, and the likely cosmetic outcome. Most patients have an unrealistic notion of the invisibility of scars, and poor appearance because of bad or inappropriate surgery is likely to have increasing medícolegal implications.

Skin malignancies comprise $25 \%$ of the cancers seen in our histopathology department. Our results suggest that general practitioners are removing more skin

Sex and age of patients with malignant lesions and site and diagnoses of lesions removed by general practitioners

\begin{tabular}{lllll}
\hline Sex & Age & $\begin{array}{l}\text { Site of } \\
\text { lesion }\end{array}$ & Clinical diagnosis & Pathological diagnosis \\
\hline F & 59 & Lip & ?Basal cell carcinoma & Basal cell carcinoma \\
M & 56 & Back & Benign & Basal cell carcinoma \\
F & 73 & Lip & Wart & Squamous cell carcinoma \\
M & 68 & Ear & Benign & Squamous cell carcinoma \\
F & 54 & Temple & Benign & Squamous cell carcinoma \\
F & 50 & Temple & ?Basal cell carcinoma & Basal cell carcinoma \\
F & 81 & Temple & ?Basal cell carcinoma & Basal cell carcinoma \\
F & 90 & Forehead & ?Sebaceous cyst & Basal cell carcinoma \\
M & 82 & Hand & Wart & Squamous cell carcinoma \\
F & 18 & Foot & Naevus & Melanoma \\
M & 68 & Arm & ?Melanoma & Melanoma \\
M & 47 & Chest & ?Basal cell carcinoma & Basal cell carcinoma \\
M & 84 & Head & Wart & Squamous cell carcinoma \\
F & 54 & Arm & ?Melanoma & Melanoma \\
M & 54 & Forehead & ?Basal cell carcinoma & Squamous cell carcinoma \\
M & 64 & Chest & ?Malignant & Basal cell carcinoma \\
F & 92 & Thigh & ?Malignant & Squamous cell carcinoma \\
F & 88 & Neck & ?Malignant & Basal cell carcinoma \\
F & 67 & Hand & ?Malignant & Squamous cell carcinoma \\
F & 76 & Hand & Basal cell carcinoma & Basal cell carcinoma \\
M & 38 & Back & Benign & Basal cell carcinoma \\
F & 45 & Neck & Naevus & Basal cell carcinoma \\
F & 44 & Face & Cyst & Melanoma \\
M & 47 & Face & ?Basal cell carcinoma & Basal cell carcinoma \\
F & 56 & Eyelid & Suspicious & Basal cell carcinoma \\
M & 56 & Back & Basal cell carcinoma & Basal cell carcinoma \\
\hline & & & &
\end{tabular}

^Incomplete excision. 